\title{
Effect of different growing media and chemical fertilization on growth and chemical composition of ponytail palm (Beaucarnea recurvata) plant
}

\author{
Youssef, A.S.M. \\ Hort. Dept., Fac. Agric., Moshtohor, Benha University, Egypt
}

\begin{abstract}
A pot experimental trial was carried out to study the effect of 15 treatments which was represented by the combination between five different growing media, i.e. clay + sand, clay + sand + composted leaves, clay + sand + peat moss, clay + sand + vermiculite and composted leaves + peat moss + vermiculite (1:1:1 by volume) and three chemical fertilization rates (a kristalon fertilizer at $0.0,3$ and $6 \mathrm{~g} / \mathrm{pot}$ ) on the growth and chemical composition of Beaucarnea recurvata plants. Results showed that growing Beaucarnea recurvata plants in a mixture medium containing clay + sand + composted leaves (1:1:1 by volume) and supplemented with kristalon fertilizer at $6 \mathrm{~g} /$ pot produced the tallest plant, the highest leaf $\mathrm{P}$, auxin and gibberellins contents. Besides, the highest values of the number, fresh and dry weights of leaves/plant as well as the highest leaf $\mathrm{K}$ content were recorded by Beaucarnea plants grown in a mixture medium involving clay + sand + peat moss and supplied with kristalon fertilizer at $6 \mathrm{~g} / \mathrm{pot}$ in both seasons. In addition, the highest caudex length was registered by using a mixture medium containing clay + sand + vermiculite which received kristalon fertilizer at $6 \mathrm{~g} /$ pot. Moreover, plants grown in composted leaves+ peat moss+ vermiculite mixture and received kristalon fertilizer at $6 \mathrm{~g} / \mathrm{pot}$ induced the highest values of caudex diameter, plant width, show value, leaf $\mathrm{N}$, total carbohydrates and cytokinins contents as well as the lowest leaf abscisic content. Conclusively, growing Beaucarnea recurvata plants in a medium containing composted leaves + peat moss + vermiculite or a medium composed of clay + sand + peat moss $(1: 1: 1$ by volume) and supplemented with kristalon fertilizer at $6 \mathrm{~g} / \mathrm{pot}$ produced the best growth and quality of this plant.
\end{abstract}

Key words: Beaucarnea recurvata, growing media, chemical fertilization, growth and chemical constituents.

Corresponding Author: E-mail: ahmed.youssef@fagr.bu.edu.eg

\section{Introduction}

Beaucarnea recurvata is native to Mexico. These plants are in the Nolinaceae family, which has recently been split out from the Agavaceae family. Beaucarnea has the potential to become huge-up to six feet in diameter at the base (caudex) and up to 25 feet tall. Flowers occur on mature plants and are spikes of small, creamy-white flowers. Beaucarnea recurvata plants have several common names as ponytail palm, bottle palm, elephant's foot and nolina. The common ponytail palm of houseplant fame makes a striking specimen plant for any landscape situation. It is also a very clean plant with no spines and can be useful around a pool. It is a very important and popular plant used in the in-door and out-doors of ornamentation as well as for purifying the air in and out doors. When planting a lot of small plants close together while maturing, their bases start to overlap one another. This leads to a very interesting effect creating a mini-forest of sizeable ponytail palms, some with bases touching or overlapping (Ismail, 2004). It is known that potting media as well as nutritional requirements are the most important factors affecting ornamental pot plants well-being. Since, there are many plants which spend their life cycle in pots and they need a medium which provides them with their different needs completely, so it is necessary to find suitable media consisted of a number of necessary components in order to achieve this purpose.

The purpose of a container medium is to physically support the plant and to supply adequate oxygen, water and nutrients for proper root functions. The plant must be held upright in the medium and the medium must be heavy enough to stabilize the container and keep it in an upright position. A balance between available water and aeration in the growth medium is essential for production of quality plants in containers. There must be adequate small pore space to hold water for plant uptake and enough large pores to allow exchange of air in the medium to maintain critical oxygen concentrations. Anaerobic conditions (without oxygen) do not allow the roots to obtain energy from the respiratory process and encourage disease development. Energy is required for root growth, proper hormone balance and nutrient uptake as well as maintenance of cell and organelle membranes. The optimal container medium will minimize the amount of management required for quality plant production.

The production of ornamental pot plants involves a number of cultural inputs, among these, perhaps the most important is the type of growing medium used. The composition of a growing medium should be well drained. Low in soluble salts, 
with an adequate exchange capacity. Since, innumerable amendment combinations can produce a growing medium with these characteristics, it is important to consider the economic, cultural optimums, transportation, labor and handling. It can be said that sand, clay, peat moss, perlite, vermiculite and organic matter are the basic components of the special medium of planting (Hartmann et al., 2002). Clay has a relatively high cation exchange and water holding capacity. Sand is the least expensive and the heaviest of all inorganic amendments. Peat moss is the most desirable organic matter for the preparation of growing media and is the most widely used substrate for potted plant production in nurseries and it accounts for a significant portion of the material used to grow potted plants (Ribeiro et al., 2007). Vermiculite has a very high water holding capacity, excellent ex-change, buffering capacities and aid in aeration and drainage it is less durable than sand and perlite (El-Khateeb et al., 2006). When composted leaves are added to the growing media, it leads to decrease soil $\mathrm{pH}$ which in turn increases solubility of nutrients for plant uptake. In some cases organic materials may act as low release fertilizers. Also, they improve soil fertility, and stimulate root development, induce active biological conditions and enhance activities of micro-organisms especially those involved in mineralization (Suresh et al., 2004). In this respect, Kakoei and Salehi (2013) reported that growing Spathiphyllum wallisii Regel plants in a mixture medium containing composted leaves, peat moss and sand induced the best growth and chemical constituents of this plant.

Fertilizing plants causes them to grow more rapidly and efficiently, just like ensuring a manufacturing plant has all the raw materials it needs for a production line. Fertilizers are essential to produce out the best features of ornamental potted plants. For natural plants to grow and thrive they need a number of chemical elements, but the most important are nitrogen, phosphorus and potassium. Most packaged fertilizers contain these three macronutrients. Nitrogen is especially important, and every amino acid in plants contains nitrogen as an essential component for plants to manufacture new cells (Marschner, 1997). Phosphorus which has been called the key to life is essential for cell division and for development of meristematic tissues and it is very important for carbohydrate transformation due to multitude of phosphorylation reaction and to energy rich phosphate bond (Lambers $\boldsymbol{e t}$ al., 2000). Potassium is important for growth and elongation probably due to its function as an osmoticum and may react synergistically with IAA. Moreover, it promotes $\mathrm{CO}_{2}$ assimilation and translocation of carbohydrates from the leaves to storage tissues (Mengel and Kirkby, 1987). In this concern, Youssef and Abd El-Aal (2014) indicated that treating Hippeastrum vittatum plants with chemical fertilizer (NPK) at $6 \mathrm{~g} /$ plant improved the growth and chemical composition as compared with un-treated plants.

\section{Materials and Methods}

A pot experimental study was carried out at the Floriculture Nursery of the Horticulture Department, Faculty of Agriculture at Moshtohor, Benha University, during 2010/2011 and 2011/2012 seasons to evaluate the effect of some different mixture media and chemical fertilization as well as their combination on growth and chemical composition of Beaucarnea recurvata plants.

Plant Material: Uniform Beaucarnea recurvata plants having 20-25 leaves and 28-32 cm height were selected for achieving this investigation. The plants were obtained from Floriculture Nursery of the Horticulture Department, Faculty of Agriculture at Moshtohor, Benha University. The plants were repotted in plastic pots of $30 \mathrm{~cm}$ diameter (one plant / pot) packed with the five chosen growing media, mention later, and placed in a partial shade under lath house condition on $1^{\text {st }}$ October, in both seasons (2010/2011 and 2011/2012).

\section{Procedure and Lay-out of the Experiment:}

Two factors were involved in the present study, the first was the growing medium the second was chemical fertilization. The different five growing media chosen; clay + sand ( $1: 1$ by volume), clay + sand + composted leaves, clay + sand + peat moss, clay + sand + vermiculite and composted leaves + peat moss + vermiculite $(1: 1: 1$ by volume). All media were analyzed for their chemical characteristics (Table, a).

The chemical fertilization rates of $0.0,3$ and 6 $\mathrm{g} /$ pot were applied monthly as a dressing application for ten times throughout the growing season. The kristalon chemical fertilizer NPK (19:19:19) was used. The fertilization treatments started from 15 January in both seasons (2010/2011 and 2011/2012) until reaching the end of experiment. Kristalon fertilizer analysis: Nitrogen 19\%, $\mathrm{P}_{2} \mathrm{O} 519 \%, \mathrm{~K}_{2} \mathrm{O}$ $19 \%$, chelated Zinc $0.0014 \%$, chelated Iron $0.0070 \%$, chelated Manganese $0.0042 \%$, chelated Cupper $0.0016 \%$, chelated Magnesium $0.0120 \%$, Molybdenum $0.0014 \%$ and Boron $0.0022 \%$. Common agricultural practices (irrigation, manual weed control, etc.) were carried out as and when needed.

The layout of the experiment was designed to provide a factorial experiment in randomized complete blocks. The study contained 15 treatments (5 growing media $\mathrm{x} 3$ rates of chemical fertilization) with three replicates. Each replicate contained 5 pots. The study was terminated on $30^{\text {th }}$ October during the two seasons. 
Table a. The mean chemical characteristics of the five chosen growing media.

\begin{tabular}{lcccccc}
\hline \multicolumn{1}{c}{ Media (1:1:1 by volume) } & $\mathrm{pH}$ & $\begin{array}{c}\mathrm{EC} \\
\left(\mathrm{dS} . \mathrm{m}^{-1}\right)\end{array}$ & $\begin{array}{c}\text { Organic } \\
\text { matter } \\
(\%)\end{array}$ & $\begin{array}{c}\text { Available } \\
\text { nitrogen } \\
(\mathrm{mg} / \mathrm{Kg})\end{array}$ & $\begin{array}{c}\text { Available } \\
\text { phosphorus } \\
(\mathrm{mg} / \mathrm{Kg})\end{array}$ & $\begin{array}{c}\text { Available } \\
\text { potassium } \\
(\mathrm{mg} / \mathrm{Kg})\end{array}$ \\
\hline Clay+Sand & 7.8 & 0.72 & 1.42 & 3421 & 532 & 736 \\
Clay+Sand+composted leaves & 6.9 & 1.21 & 2.37 & 4830 & 634 & 879 \\
Clay+Sand+peat moss & 6.8 & 0.93 & 2.14 & 4621 & 592 & 864 \\
Clay+Sand+vermiculite & 7.2 & 0.62 & 1.12 & 3142 & 512 & 721 \\
Compost.+peat & 6.7 & 0.67 & 2.78 & 5216 & 783 & 983 \\
moss+vermiculite & & & & & & 736 \\
\hline
\end{tabular}

\section{Recorded data:}

\section{1-Growth parameters:}

Plant height, number of leaves/plant, fresh and dry weights of leaves/plant, length and diameter of caudex (stem base), plant width, show value; as plant width / plant height ratio according to Berghage $\boldsymbol{e t}$ al. (1989), fresh and dry weights of roots/plant.

2- Leaf chemical composition determinations:

a- Total nitrogen percentage was determined in the dried leaves by using the modified micro-kjeldahl method as described by Pregl (1945).

b- Phosphorus was determined colourimetrically in a spectronic (20) spectrophotometer using the method described by Trouge and Meyer (1939).

c- Potassium content was determined by a flame photometer according to Brown and Lilleland (1946).

d- Total carbohydrates content was determined in dried leaf powder according to Herbert et al. (1971). e - Endogenous phytohormones:

Endogenous phytohormones were quantitatively determined in Beaucarnea recurvata leaves in the second season using High- Performance Liquid Chromato-graphy (HPLC) according to Koshioka $\boldsymbol{e t}$ al. (1983) for auxin (IAA), gibberellins and abscisic acid (ABA), while cytokinins were determined according to Nicander et al. (1993).

All recorded data of Beaucarnea recurvata were taken at the end of experiment.

\section{Statistical analysis:}

All obtained data in both seasons of study were subjected to analysis of variance as factorial experiments in a complete randomized block design. L.S.D. method was used to differentiate between means according to Snedecor and Cochran (1989).

\section{Results and Discussion}

I- Effect of some growing media and NPK fertilization on some growth parameters of Beaucarnea recurvata plants

\section{1-Plant height}

Data in Table (1) show that the different growing media have significantly affected plant height, especially using a medium containing 1 part clay: 1 part sand: 1 part composted leaves compared with the other media in both seasons. Data concerning the effect of NPK fertilization on plant height obviously revealed that increasing NPK fertilization levels from 0.0 to $6 \mathrm{~g} /$ pot caused a gradual increment in this parameter in both seasons. The interaction effect between growing media and NPK fertilization (kristalon fertilizer) had a positive effect on plant height as the tallest plants (72.50 and $74.21 \mathrm{~cm}$ ) were obtained on plants grown in a mixture medium involving clay + sand + composted leaves at a ratio of $1: 1: 1$ by volume which received NPK fertilization at $6 \mathrm{~g} / \mathrm{pot}$, in the first and second seasons, respectively. On contrary, the lowest values of plant height (42.35 and 38.64) were scored by using a medium containing clay and sand $(1: 1$ by volume) and receiving no NPK fertilization in the first and second seasons, respectively.

\section{2-Number, fresh and dry weights of leaves /plant.}

Data in Tables (1and 2) indicate that using a medium containing clay + sand + peat moss $(1: 1: 1$ by volume) gave the highest values of the number, fresh and dry weights of leaves /plant, followed by using the growing medium containing clay + sand + composted leaves (1:1:1 by volume) in both seasons. Also, all tested applications of NPK fertilization significantly increased the values of these parameters, especially using the highest level $(6 \mathrm{~g} / \mathrm{pot})$ as compared with un-treated plants in both seasons. As for the interaction effect between growing media and NPK fertilization, data in Tables (1 and 2) reveal that all resulted combinations between growing media and NPK fertilization at 3 or $6 \mathrm{~g} /$ pot succeeded in increasing the values of these parameters, with superiority for the combination of NPK fertilization at $6 \mathrm{~g} /$ pot in both seasons. However, the highest number of leaves/plant ( 76.80 and $71.24)$, the heaviest fresh weight of leaves/plant ( 326.8 and $298.2 \mathrm{~g}$ ) and the heaviest dry weights of leaves /plant ( 55.74 and $50.06 \mathrm{~g}$ ) were recorded by the plants grown in a medium containing clay + sand + peat moss and received NPK fertilization at $6 \mathrm{~g}$ /pot, in the first and second seasons, respectively. 
Table 1. Effect of growing media and NPK fertilization treatments on plant height and leaves number of Beaucarnea recurvata plants during 2010/2011 and 2011/2012 seasons.

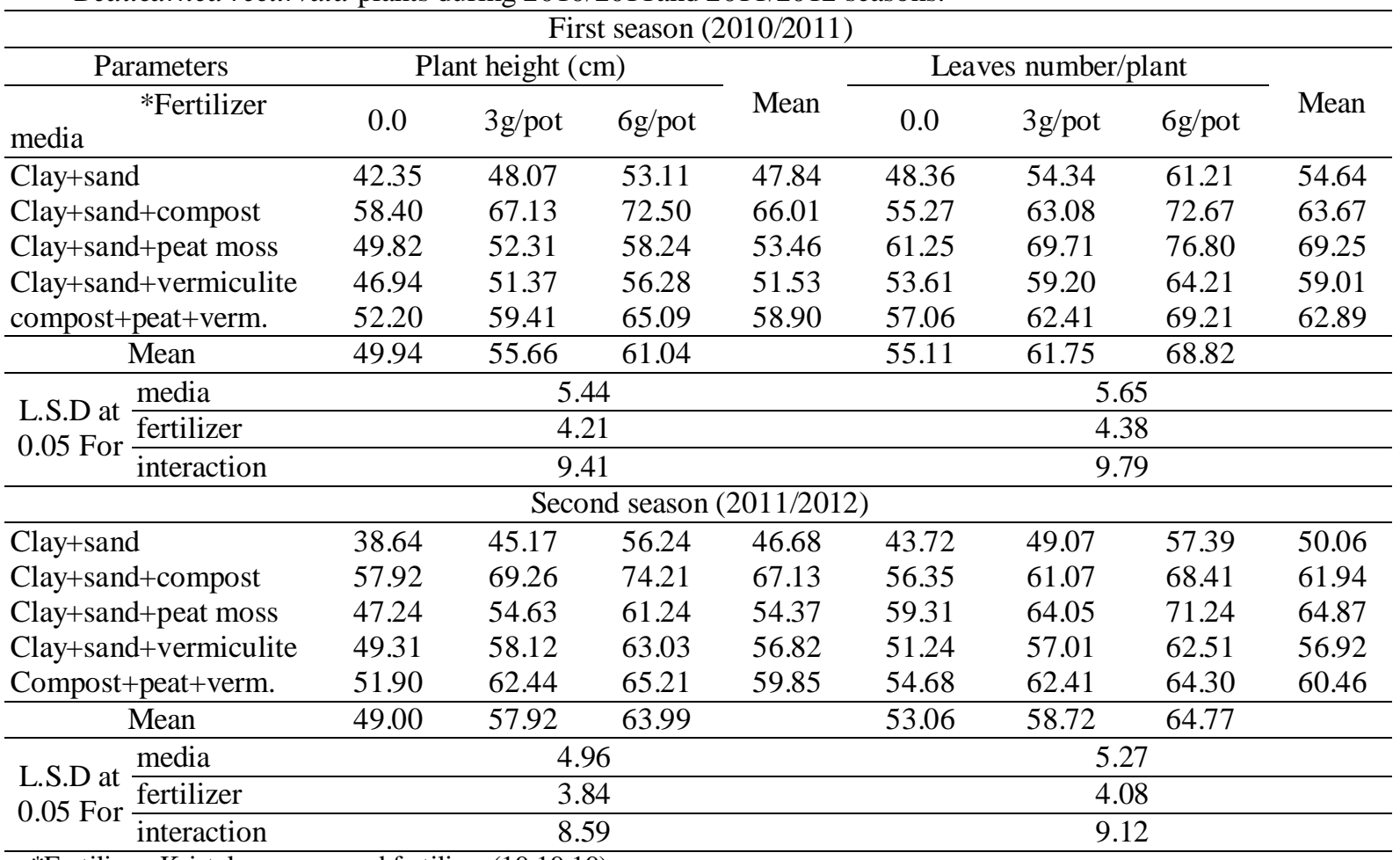

*Fertilizer: Kristalon compound fertilizer (19:19:19)

Table 2. Effect of growing media and NPK fertilization treatments on fresh and dry weights of leaves of Beaucarnea recurvata plants during 2010/2011 and 2011/2012 seasons.

\begin{tabular}{|c|c|c|c|c|c|c|c|c|}
\hline \multicolumn{8}{|c|}{ First season $(2010 / 2011)$} & \multirow[b]{3}{*}{ Mean } \\
\hline Parameters & \multicolumn{3}{|c|}{ Fresh weight of leaves $(\mathrm{g})$} & \multirow[b]{2}{*}{ Mean } & \multicolumn{3}{|c|}{ Dry weight of leaves $(\mathrm{g})$} & \\
\hline *Fertilizer & 0.0 & $3 \mathrm{~g} /$ pot & $6 \mathrm{~g} /$ pot & & 0.0 & $3 \mathrm{~g} /$ pot & $6 \mathrm{~g} /$ pot & \\
\hline Clay+sand & 148.8 & 189.0 & 225.7 & 187.8 & 23.95 & 30.81 & 37.57 & 30.78 \\
\hline Clay+sand+compost & 187.0 & 239.4 & 295.2 & 240.5 & 30.48 & 39.67 & 49.56 & 39.90 \\
\hline Clay+sand+peat moss & 195.6 & 234.6 & 326.8 & 252.3 & 32.17 & 39.31 & 55.74 & 42.41 \\
\hline Clay+sand+vermiculite & 169.6 & 200.6 & 236.8 & 202.3 & 27.71 & 33.60 & 39.88 & 33.73 \\
\hline Compost+peat+verm. & 182.4 & 217.0 & 255.3 & 218.2 & 29.84 & 36.23 & 42.84 & 36.30 \\
\hline Mean & 176.68 & 216.12 & 267.96 & & 28.83 & 35.92 & 45.12 & \\
\hline media & \multicolumn{4}{|c|}{15.93} & \multicolumn{4}{|c|}{3.80} \\
\hline L.S.D at fertilizer & \multicolumn{4}{|c|}{12.34} & \multicolumn{4}{|c|}{2.94} \\
\hline 0.0J For interaction & \multicolumn{4}{|c|}{27.59} & \multirow{2}{*}{\multicolumn{3}{|c|}{6.57}} & \\
\hline \multicolumn{6}{|c|}{ Second season $(2011 / 2012)$} & & & \\
\hline Clay+sand & 141.9 & 171.5 & 210.9 & 174.8 & 22.98 & 28.56 & 35.28 & 28.94 \\
\hline Clay+sand+compost & 190.4 & 219.6 & 265.2 & 225.1 & 31.54 & 36.79 & 44.78 & 37.70 \\
\hline Clay+sand+peat moss & 200.5 & 243.2 & 298.2 & 247.3 & 33.20 & 40.58 & 50.06 & 41.28 \\
\hline Clay+sand+vermiculite & 163.2 & 199.5 & 235.6 & 199.4 & 26.73 & 33.23 & 39.48 & 33.15 \\
\hline Compost+peat+verm. & 183.6 & 223.2 & 243.2 & 216.7 & 30.01 & 37.24 & 40.82 & 36.02 \\
\hline Mean & 175.9 & 211.4 & 250.6 & & 28.89 & 35.28 & 42.08 & \\
\hline \multirow{3}{*}{$\begin{array}{lr}\text { L.S.D at } & \text { media } \\
0.05 \text { For } & \text { fertilizer }\end{array}$} & \multicolumn{4}{|c|}{22.02} & \multicolumn{4}{|c|}{3.54} \\
\hline & \multicolumn{4}{|c|}{17.06} & \multicolumn{4}{|c|}{2.74} \\
\hline & \multicolumn{4}{|c|}{38.15} & \multicolumn{4}{|c|}{6.13} \\
\hline
\end{tabular}

*Fertilizer: Kristalon compound fertilizer (19:19:19)

\section{3-Length and diameter of caudex:}

Data in Table (3) demonstrate that the highest caudex (stem base) length was scored by using a mixture medium of clay + sand + vermiculite, whereas the highest caudex diameter was gained by using a medium containing composted leaves+ peat moss+ vermiculite as compared with the other growing media in both seasons. In addition, both 
levels of NPK fertilization significantly increased the length and diameter of caudex, particularly the high level when compared with un-fertilized plants in both seasons. Referring to the interaction effect between growing media and NPK fertilization, data in the same Table, declare that all resulted interactions increased the length and diameter of caudex in both seasons. However, the highest caudex length ( 15.18 and $14.93 \mathrm{~cm}$ ) and the highest caudex diameter $(15.68$ and $16.76 \mathrm{~cm})$ were registered by using the mixture media of clay + sand + vermiculite and composted leaves+ peat moss+ vermiculite and both receiving NPK fertilization at $6 \mathrm{~g} / \mathrm{pot}$, respectively.

Table 3. Effect of growing media and NPK fertilization treatments on caudex length and caudex diameter of Beaucarnea recurvata plants during 2010/2011 and 2011/2012 seasons.

\begin{tabular}{|c|c|c|c|c|c|c|c|c|}
\hline \multicolumn{9}{|c|}{ First season (2010/2011) } \\
\hline Parameters & \multicolumn{3}{|c|}{ Caudex length $(\mathrm{cm})$} & \multirow[b]{2}{*}{ Mean } & \multicolumn{3}{|c|}{ Caudex diameter $(\mathrm{cm})$} & \multirow[b]{2}{*}{ Mean } \\
\hline *Fertilizer & 0.0 & $3 \mathrm{~g} /$ pot & $6 \mathrm{~g} / \mathrm{pot}$ & & 0.0 & $3 \mathrm{~g} /$ pot & $6 \mathrm{~g} /$ pot & \\
\hline Clay+sand & 11.74 & 12.60 & 14.23 & 12.86 & 12.94 & 13.72 & 14.72 & 13.79 \\
\hline Clay+sand+compost & 10.24 & 12.19 & 11.94 & 11.46 & 11.78 & 13.07 & 13.28 & 12.71 \\
\hline Clay+sand+peat moss & 11.34 & 13.16 & 12.84 & 12.45 & 13.15 & 14.92 & 14.80 & 14.29 \\
\hline Clay+sand+vermiculite & 11.94 & 13.26 & 15.18 & 13.46 & 11.02 & 12.41 & 13.10 & 12.18 \\
\hline Compost+peat+verm. & 10.80 & 11.86 & 12.91 & 11.86 & 13.87 & 14.94 & 15.68 & 14.83 \\
\hline Mean & 11.21 & 12.61 & 13.42 & & 12.55 & 13.81 & 14.32 & \\
\hline \multirow{3}{*}{$\begin{array}{l}\text { L.S.D at } \frac{\text { media }}{\text { fertilizer }} \\
0.05 \text { For } \frac{\text { interaction }}{\text { inter }}\end{array}$} & \multicolumn{4}{|c|}{0.49} & \multicolumn{4}{|c|}{0.54} \\
\hline & \multicolumn{4}{|c|}{0.38} & \multicolumn{4}{|c|}{0.42} \\
\hline & \multicolumn{4}{|c|}{0.85} & \multicolumn{4}{|c|}{0.94} \\
\hline \multicolumn{9}{|c|}{ Second season $(2011 / 2012)$} \\
\hline Clay+sand & 10.94 & 11.87 & 12.64 & 11.82 & 11.87 & 14.21 & 14.08 & 13.39 \\
\hline Clay+sand+compost & 11.76 & 12.90 & 13.81 & 12.82 & 10.28 & 13.48 & 14.67 & 12.81 \\
\hline Clay+sand+peat moss & 10.22 & 11.08 & 12.13 & 11.14 & 12.19 & 14.81 & 15.21 & 14.07 \\
\hline Clay+sand+vermiculite & 11.79 & 13.42 & 14.93 & 13.38 & 10.45 & 12.61 & 13.41 & 12.16 \\
\hline Compost+peat+verm. & 11.21 & 12.83 & 12.70 & 12.25 & 14.17 & 15.90 & 16.76 & 15.61 \\
\hline Mean & 11.18 & 12.42 & 13.24 & & 11.79 & 14.20 & 14.83 & \\
\hline media & \multicolumn{4}{|c|}{0.44} & \multicolumn{4}{|c|}{0.61} \\
\hline L.S.D at fertilizer & \multicolumn{4}{|c|}{0.34} & \multicolumn{4}{|c|}{0.47} \\
\hline 0.05 For interaction & \multicolumn{4}{|c|}{0.76} & \multicolumn{4}{|c|}{1.05} \\
\hline
\end{tabular}

*Fertilizer: Kristalon compound fertilizer (19:19:19)

\section{4-Plant width and show value:}

Data in Table (4) exhibit that the mixture of composted leaves + peat moss + vermiculite showed to be the most effective one for producing the widest plant and the greatest show value as compared with the other mixtures media in both seasons.

Additionally, all tested NPK applications significantly increased the plant width as compared with untreated plants, but it failed to induce significant differences in case of the show value parameter in both seasons. Moreover, the interaction effect between growing media and NPK fertilization reveal that plants grown in composted leaves+ peat moss+ vermiculite mixture and receiving chemical fertilizer at $6 \mathrm{~g} /$ pot induced the highest values of plant width $(49.34$ and $53.24 \mathrm{~cm})$ and show value (0.758 and 0.816) in the first and second seasons, respectively.

\section{5-Fresh and dry weights of roots/plant:}

It is obvious from Table (5) that using a mixture medium containing clay + sand + peat moss was more effective in increasing the fresh and dry weights of roots/plant as compared with the other growing media in both seasons. Besides, fresh and dry weights of roots/plant were greatly increased by both levels of NPK fertilization, especially the high level in both seasons. As for the interaction effect between growing media and NPK fertilization, data in Table (5) clear that grown ponytail palm plants in medium containing clay + sand + peat moss and fertilized with NPK fertilization at $6 \mathrm{~g}$ /pot is being the most effective one in inducing the heaviest fresh and dry weights of roots/pot in both seasons. The positive action of growing media on supplying the plants with their requirements from aeration, water and nutrients could explain the present results.

The aforementioned results of growing media are in conformity with those reported by Muhabat Shah et al. (2006) on Ficus binnendijkii 'Amstel Queen', Khayyat et al. (2007) on Epipremnum aureum, Kiran et al. (2007) on Dahlia pinnata, Chavez et al. (2008) on Petunia hybrida, Riaz et al. (2008) on Zinnia elegans, Younis et al. (2010) on Codiaeum variegatum, Ikram et al. (2012) on tuberose plant, Khalaj et al. (2011) on Gerbera jamesonii L., Aklibasinda et al. (2011) on Pinus sylvestris, Abouzar (2012) on Ficus benjamina, 
Table 4. Effect of growing media and NPK fertilization treatments on plant width and show value of Beaucarnea recurvata plants during 2010/2011 and 2011/2012 seasons.

\begin{tabular}{|c|c|c|c|c|c|c|c|c|}
\hline \multicolumn{9}{|c|}{ First season $(2010 / 2011)$} \\
\hline Parameters & \multicolumn{3}{|c|}{ Plant width $(\mathrm{cm})$} & \multirow{2}{*}{ Mean } & \multicolumn{3}{|c|}{$\begin{array}{c}\text { Show value } \\
\text { (plant width/height ratio) }\end{array}$} & \multirow{2}{*}{ Mean } \\
\hline *Fertilizer & 0.0 & $3 \mathrm{~g} /$ pot & $6 \mathrm{~g} /$ pot & & 0.0 & $3 \mathrm{~g} /$ pot & $6 \mathrm{~g} /$ pot & \\
\hline Clay+sand & 29.49 & 32.17 & 31.80 & 31.15 & 0.696 & 0.669 & 0.599 & 0.655 \\
\hline Clay+sand+compost & 28.31 & 34.63 & 33.21 & 32.05 & 0.485 & 0.516 & 0.458 & 0.486 \\
\hline Clay+sand+peat moss & 32.42 & 39.60 & 42.41 & 38.14 & 0.651 & 0.757 & 0.728 & 0.712 \\
\hline Clay+sand+vermiculite & 29.43 & 32.81 & 31.84 & 31.36 & 0.627 & 0.639 & 0.566 & 0.611 \\
\hline Compost+peat+verm. & 36.24 & 42.91 & 49.34 & 42.83 & 0.694 & 0.722 & 0.758 & 0.725 \\
\hline Mean & 31.18 & 36.42 & 37.72 & & 0.631 & 0.661 & 0.622 & \\
\hline \multirow{3}{*}{$\begin{array}{l}\text { L.S.D at } \frac{\text { medi }}{\text { fertil }} \\
0.05 \text { For }\end{array}$} & \multicolumn{4}{|c|}{4.12} & \multicolumn{4}{|c|}{0.14} \\
\hline & \multicolumn{4}{|c|}{3.19} & \multicolumn{4}{|c|}{ N.S } \\
\hline & \multicolumn{4}{|c|}{7.13} & \multicolumn{4}{|c|}{0.25} \\
\hline \multicolumn{9}{|c|}{ Second season $(2011 / 2012)$} \\
\hline Clay+sand & 27.43 & 34.22 & 36.20 & 32.62 & 0.710 & 0.758 & 0.644 & 0.704 \\
\hline Clay+sand+compost & 26.24 & 35.08 & 36.17 & 32.50 & 0.453 & 0.506 & 0.487 & 0.482 \\
\hline Clay+sand+peat moss & 31.06 & 41.93 & 47.21 & 40.07 & 0.657 & 0.768 & 0.771 & 0.732 \\
\hline Clay+sand+vermiculite & 28.41 & 36.01 & 39.25 & 34.56 & 0.576 & 0.620 & 0.623 & 0.606 \\
\hline Compost+peat+verm. & 34.07 & 45.30 & 53.24 & 44.20 & 0.656 & 0.687 & 0.816 & 0.720 \\
\hline Mean & 29.44 & 38.51 & 42.41 & & 0.610 & 0.668 & 0.668 & \\
\hline \multirow{3}{*}{$\begin{array}{l}\text { L.S.D at } \\
0.05 \text { For } \frac{\text { fertilizer }}{\text { interaction }}\end{array}$} & \multicolumn{4}{|c|}{4.65} & \multicolumn{4}{|c|}{0.12} \\
\hline & \multicolumn{3}{|c|}{3.60} & & \multicolumn{4}{|c|}{ N.S } \\
\hline & \multicolumn{4}{|c|}{8.05} & \multicolumn{4}{|c|}{0.20} \\
\hline
\end{tabular}

*Fertilizer: Kristalon compound fertilizer (19:19:19)

Table 5. Effect of growing media and NPK fertilization treatments on fresh and dry weights of roots of Beaucarnea recurvata plants during 2010/2011 and 2011/2012 seasons.

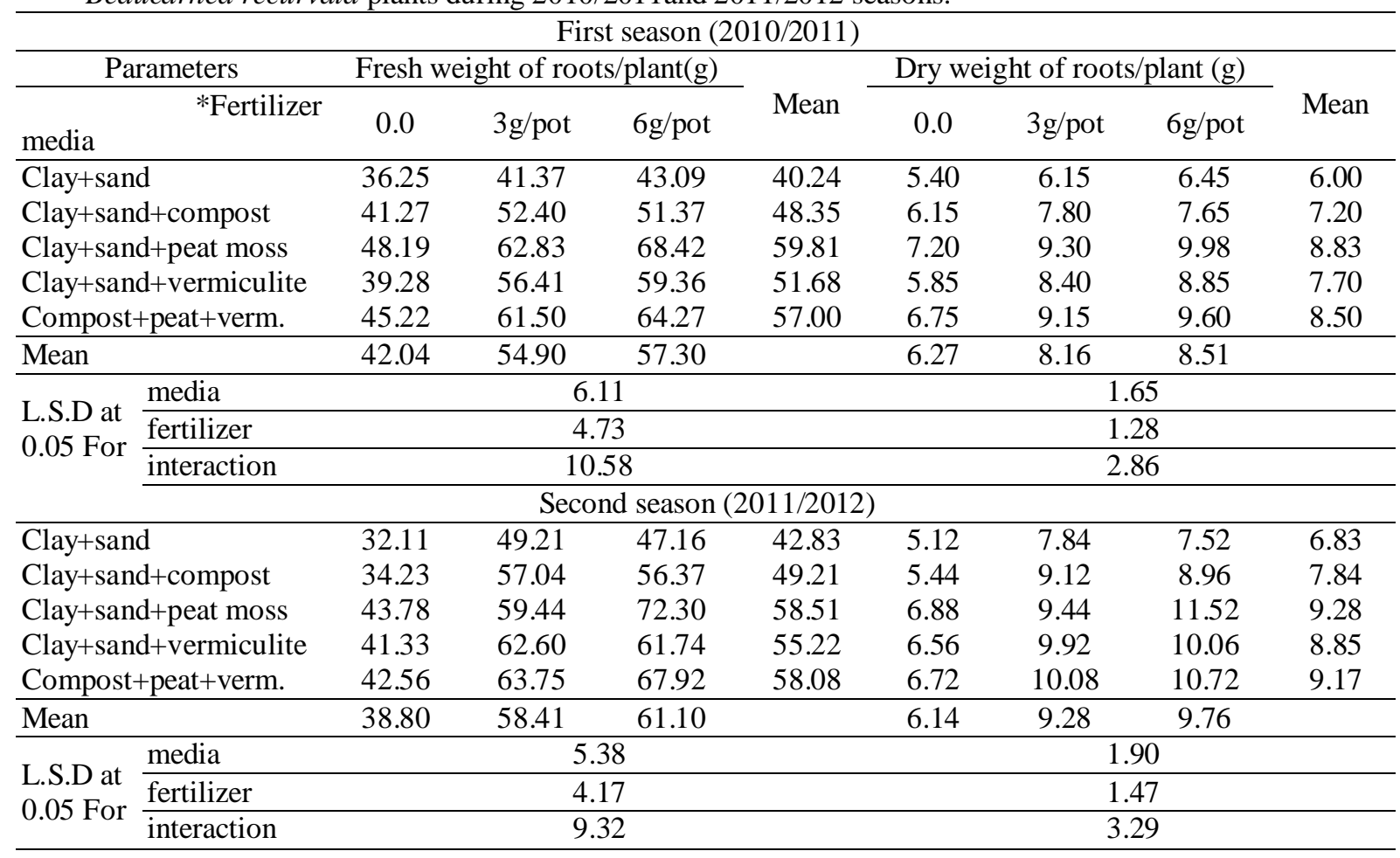

Yousif and Kako (2012) on Hyacinthus orientalis L., Kakoei and Salehi (2013) on Spathiphyllum wallisii Regel, Herath et al. (2013) on Ophiopogon sp. and Tahir et al. (2013) on Antirrhinum majus L.
The abovementioned results of chemical fertilization are in harmony with those attained by Singh et al. (2002) on Gladiolus grandiflorum, Pal and Biswas (2005) on Polianthes tuberosa L., El- 
Malt et al. (2006) on Hippeastrum vittatum, Youssef and Gomaa (2007) on Iris tingitana, Abou El-Ella (2007) on Acanthus mollis, El-Naggar and ElNasharty (2009) on Hippeastrum vittatum, Hussein (2009) on Cryptostegia grandiflora, Abd El-All (2011) on Aspidistra elatior, Habib (2012) on Caryota mitis Lour, Wanderley et al. (2012) on areca bamboo palm (Dypsis lutescens) and Youssef and Abd El-Aal (2014) again on Hippeastrum vittatum.

\section{II- Effect of some growing media and NPK fertilization on some chemical constituents of Beaucarnea recurvata plants}

1- Leaf N, P, K and total carbohydrates contents:

Data in Tables (6\&7) indicate that all used growing media and NPK fertilization as well as their interactions had a pronounced effect on increasing leaf $\mathrm{N}, \mathrm{P}, \mathrm{K}$ and total carbohydrates contents of Beaucarnea recurvata plants in both seasons. However, the highest values of both leaf $\mathrm{N}$ and total carbohydrates content were scored by using the mixture medium of composted leaves+ peat moss+ vermiculite, whereas the highest values of both leaf $\mathrm{P}$ and $\mathrm{K}$ contents were registered by growing the plants in the mixture media of clay + sand + composted leaves and clay + sand + peat moss which received chemical fertilizer at $6 \mathrm{~g} /$ pot, respectively as compared with the other treatments in both seasons.
2-Endogenous phytohormones content.

Endogenous phytohormones results of Beaucarnea recurvata leaves during 2011/2012 season as affected by different growing media and chemical fertilization treatments are shown in Table (8). According to these results, all promoters (auxins, gibberellins and cytokinins) were increased by using different growing media and chemical fertilization as well as their combination, yet abscisic acid was decreased. However, the highest value of leaf cytokinins content $(16.80 \mu \mathrm{g} / \mathrm{g} \mathrm{F.W})$ as well as the lowest leaf abscisic acid content $(0.32 \mu \mathrm{g} / \mathrm{g}$ F.W $)$ were recorded by growing Beaucarnea recurvata plants in medium containing composted leaves+ peat moss+ vermiculite that received chemical fertilization at $6 \mathrm{~g} /$ pot, whereas the highest leaf auxins (31.62 $\mu \mathrm{g} / \mathrm{g} \mathrm{F.W})$ and gibberellins $(68.18 \mu \mathrm{g} / \mathrm{g} \mathrm{F} . \mathrm{W})$ contents were scored by using the medium containing clay + sand + composted leaves and fertilized with NPK fertilization at the high rate (6g/pot). These data could also be of great influence upon different vegetative growth and nutritional status of the plants. The stimulated effect of kristalon fertilizer may be due to the role of kristalon fertilizer on supplying the plants with their nutrients i.e. with more carbohydrates and proteins production which are necessary for vegetative, roots growth and chemical composition of Beaucarnea plants (Marschner, 1997).

Table 6. Effect of growing media and NPK fertilization treatments on leaf N and P contents of Beaucarnea recurvata plants during 2010/2011 and 2011/2012 seasons.

\begin{tabular}{|c|c|c|c|c|c|c|c|c|}
\hline \multicolumn{9}{|c|}{ First season $(2010 / 2011)$} \\
\hline Parameters & \multicolumn{3}{|c|}{$\mathrm{N} \%$} & \multirow[b]{2}{*}{ Mean } & \multicolumn{3}{|c|}{$\mathrm{P} \%$} & \multirow[b]{2}{*}{ Mean } \\
\hline *Fertilizer & 0.0 & $3 \mathrm{~g} /$ pot & $6 \mathrm{~g} / \mathrm{pot}$ & & 0.0 & $3 g /$ pot & $6 \mathrm{~g} / \mathrm{pot}$ & \\
\hline Clay+sand & 2.24 & 2.37 & 2.42 & 2.34 & 0.182 & 0.194 & 0.192 & 0.189 \\
\hline Clay+sand+compost & 2.32 & 2.64 & 2.79 & 2.58 & 0.193 & 0.247 & 0.254 & 0.231 \\
\hline Clay+sand+peat moss & 2.36 & 2.59 & 2.60 & 2.52 & 0.189 & 0.219 & 0.217 & 0.208 \\
\hline Clay+sand+vermiculite & 2.29 & 2.56 & 2.52 & 2.46 & 0.196 & 0.194 & 0.212 & 0.201 \\
\hline Compost+peat+verm. & 2.39 & 2.80 & 2.94 & 2.71 & 0.191 & 0.241 & 0.249 & 0.227 \\
\hline Mean & 2.32 & 2.59 & 2.65 & & 0.190 & 0.219 & 0.225 & \\
\hline \multirow{4}{*}{$\begin{array}{l}\text { L.S.D at } \\
0.05 \text { For } \frac{\text { fertilizer }}{\text { interacti }}\end{array}$} & \multicolumn{4}{|c|}{0.15} & \multicolumn{4}{|c|}{0.018} \\
\hline & \multicolumn{4}{|c|}{0.12} & \multicolumn{4}{|c|}{0.014} \\
\hline & \multicolumn{4}{|c|}{0.27} & \multicolumn{4}{|c|}{0.031} \\
\hline & \multicolumn{8}{|c|}{ Second season $(2011 / 2012)$} \\
\hline Clay+sand & 2.16 & 2.46 & 2.43 & 2.35 & 0.191 & 0.212 & 0.219 & 0.207 \\
\hline Clay+sand+compost & 2.26 & 2.39 & 2.40 & 2.35 & 0.203 & 0.256 & 0.262 & 0.240 \\
\hline Clay+sand+peat moss & 2.28 & 2.38 & 2.35 & 2.34 & 0.192 & 0.191 & 0.214 & 0.199 \\
\hline Clay+sand+vermiculite & 2.21 & 2.31 & 2.35 & 2.29 & 0.194 & 0.233 & 0.229 & 0.219 \\
\hline Compost+peat+verm. & 2.29 & 2.68 & 2.84 & 2.60 & 0.198 & 0.241 & 0.253 & 0.231 \\
\hline Mean & 2.24 & 2.44 & 2.47 & & 0.196 & 0.227 & 0.235 & \\
\hline \multirow{3}{*}{$\begin{array}{l}\text { L.S.D at } \frac{\text { media }}{\text { fertilizer }} \\
0.05 \text { For } \frac{\text { interaction }}{\text { intion }}\end{array}$} & \multicolumn{4}{|c|}{0.14} & \multicolumn{4}{|c|}{0.015} \\
\hline & \multicolumn{4}{|c|}{0.11} & \multicolumn{4}{|c|}{0.012} \\
\hline & \multicolumn{4}{|c|}{0.25} & \multicolumn{4}{|c|}{0.027} \\
\hline
\end{tabular}

\footnotetext{
*Fertilizer: Kristalon compound fertilizer (19:19:19)
} 
Table 7. Effect of growing media and NPK fertilization treatments on leaf K and total carbohydrates contents of Beaucarnea recurvata plants during 2010/2011 and 2011/2012 seasons.

\begin{tabular}{|c|c|c|c|c|c|c|c|c|}
\hline \multicolumn{9}{|c|}{ First season $(2010 / 2011)$} \\
\hline Parameters & \multicolumn{3}{|c|}{$\mathrm{K} \%$} & \multirow[b]{2}{*}{ Mean } & \multicolumn{3}{|c|}{ Total carbohydrates \% } & \multirow[b]{2}{*}{ Mean } \\
\hline *Fertilizer & 0.0 & $3 \mathrm{~g} /$ pot & $6 \mathrm{~g} /$ pot & & 0.0 & $3 \mathrm{~g} /$ pot & $6 \mathrm{~g} /$ pot & \\
\hline Clay+sand & 1.53 & 1.84 & 1.93 & 1.77 & 12.11 & 13.94 & 14.83 & 13.63 \\
\hline Clay+sand+compost & 1.81 & 2.43 & 2.41 & 2.22 & 12.36 & 16.21 & 15.96 & 14.84 \\
\hline Clay+sand+peat moss & 1.83 & 2.46 & 2.52 & 2.27 & 12.40 & 15.30 & 17.21 & 14.97 \\
\hline Clay+sand+vermiculite & 2.14 & 2.11 & 2.20 & 2.15 & 12.65 & 15.14 & 15.74 & 14.51 \\
\hline Compost+peat+verm. & 1.89 & 2.37 & 2.45 & 2.24 & 14.15 & 16.93 & 18.26 & 16.45 \\
\hline Mean & 1.84 & 2.24 & 2.30 & & 12.73 & 15.50 & 16.40 & \\
\hline \multirow{3}{*}{$\begin{array}{l}\text { L.S.D at } \frac{\text { media }}{\text { fertilizer }} \\
0.05 \text { For } \frac{\text { interaction }}{n}\end{array}$} & \multicolumn{4}{|c|}{0.35} & \multicolumn{4}{|c|}{1.59} \\
\hline & \multicolumn{4}{|c|}{0.27} & \multicolumn{4}{|c|}{1.23} \\
\hline & \multicolumn{4}{|c|}{0.60} & \multicolumn{4}{|c|}{2.75} \\
\hline \multicolumn{9}{|c|}{ Second season $(2011 / 2012)$} \\
\hline Clay+sand & 1.62 & 1.98 & 1.19 & 1.60 & 10.39 & 14.12 & 14.92 & 13.14 \\
\hline Clay+sand+compost & 1.96 & 1.94 & 2.14 & 2.01 & 11.08 & 14.82 & 14.96 & 13.62 \\
\hline Clay+sand+peat moss & 1.93 & 2.54 & 2.61 & 2.36 & 12.14 & 15.94 & 17.16 & 15.08 \\
\hline Clay+sand+vermiculite & 1.87 & 2.34 & 2.28 & 2.16 & 11.18 & 15.37 & 15.29 & 13.95 \\
\hline Compost+peat+verm. & 1.90 & 2.43 & 2.50 & 2.28 & 13.64 & 17.82 & 18.93 & 16.80 \\
\hline Mean & 1.86 & 2.25 & 2.14 & & 11.69 & 15.61 & 16.25 & \\
\hline \multirow{3}{*}{$\begin{array}{l}\text { L.S.D at } \frac{\text { media }}{\text { fertilizer }} \\
0.05 \text { For } \frac{\text { interaction }}{\text { intion }}\end{array}$} & \multicolumn{4}{|c|}{0.27} & \multicolumn{4}{|c|}{1.51} \\
\hline & \multicolumn{4}{|c|}{0.21} & \multicolumn{4}{|c|}{1.17} \\
\hline & \multicolumn{4}{|c|}{0.47} & \multicolumn{4}{|c|}{2.62} \\
\hline
\end{tabular}

*Fertilizer: Kristalon compound fertilizer (19:19:19)

Table 8. Effect of growing media and NPK fertilization treatments on leaf endogenous phytohormones contents of Beaucarnea recurvata during 2011/2012 season.

\begin{tabular}{|c|c|c|c|c|c|c|c|c|c|c|c|c|}
\hline \multirow[b]{3}{*}{ media } & \multicolumn{9}{|c|}{ Promoters } & \multirow{2}{*}{\multicolumn{3}{|c|}{$\begin{array}{c}\text { Inhibitors } \\
\text { Abscisic acid (ABA) } \\
\mu \mathrm{g} / \mathrm{g} \text { F.wt. }\end{array}$}} \\
\hline & \multicolumn{3}{|c|}{$\begin{array}{l}\text { Cytokinins } \\
\mu \mathrm{g} / \mathrm{g} \mathrm{F} . \mathrm{W}\end{array}$} & \multicolumn{3}{|c|}{$\begin{array}{c}\text { Auxins (IAA) } \\
\mu \mathrm{g} / \mathrm{g} \text { F.W }\end{array}$} & \multicolumn{3}{|c|}{$\begin{array}{c}\text { Gibberellins }\left(\mathrm{GA}_{3}\right) \\
\mu \mathrm{g} / \mathrm{g} \text { F.W }\end{array}$} & & & \\
\hline & $0 \mathrm{~g} / \mathrm{pot}$ & $3 g /$ pot & $6 \mathrm{~g} /$ pot & $0 \mathrm{~g} /$ pot & $3 \mathrm{~g} /$ pot & $6 \mathrm{~g} /$ pot & $0 \mathrm{~g} /$ pot & $3 \mathrm{~g} /$ pot & $6 \mathrm{~g} /$ pot & $0 \mathrm{~g} / \mathrm{pot}$ & $3 \mathrm{~g} / \mathrm{pot}$ & $6 \mathrm{~g} / \mathrm{pot}$ \\
\hline Clay+sand & 10.18 & 9.20 & 11.33 & 23.71 & 25.01 & 29.23 & 37.36 & 48.91 & 51.27 & 0.68 & 0.60 & 0.52 \\
\hline Clay+sand+compost & 11.71 & 10.35 & 9.24 & 24.16 & 28.40 & 31.62 & 53.28 & 62.64 & 68.18 & 0.49 & 0.36 & 0.46 \\
\hline Clay+sand+peat moss & 11.20 & 11.78 & 13.51 & 18.22 & 27.31 & 24.20 & 36.31 & 48.20 & 39.32 & 0.61 & 0.42 & 0.57 \\
\hline Clay+sand+vermiculite & 12.14 & 12.92 & 15.06 & 23.54 & 21.74 & 25.93 & 34.30 & 54.16 & 51.02 & 0.58 & 0.54 & 0.59 \\
\hline Compost+peat+verm. & 13.16 & 14.93 & 16.80 & 19.42 & 24.09 & 21.67 & 39.04 & 46.15 & 42.51 & 0.62 & 0.39 & 0.32 \\
\hline
\end{tabular}

Generally, increments of cytokinins, auxins and gibberellins obtained in the present study could interpret the obtained results of vegetative growth (Tables, 1-5), as well as chemical constituents (Tables, 6\&7). For example, increasing cytokinins could favor increasing caudex diameter, number of formed leaves and roots as well as their fresh and dry weights. Whereas, increasing gibberellins and auxins could favor increasing plant height.

The obtained results are of great interest, since the increment of endogenous cytokinins clearly could explain the improvement of all growth characteristics obtained in the present study. Cytokinins are known as shooting hormones (Salisbury and Ross, 1974). This promotive effect of cytokinin could be illustrated herewith in this study by the improvement for example in caudex diameter, number of leaves and roots as well as in leaves fresh and dry weights. Also, of interest is to note that these treatments were accompanied with a significant increase in plant height that is being expected when related with the obtained increases in endogenous auxin and gibberellins levels. Finally, such results are of economic value ornamentally. Since more marketable characteristics were achieved for making this plant as an attractive pot plant.

The aforementioned results of growing media concerning chemical constituents are in conformity with those reported by Bashir et al. (2007) on jojoba (Simmondsia chinensis), Khelikuzzaman (2007) on Tradescantia sp., Turhan et al. (2007) on Crocus sativus L., Ostos et al. (2008) on Pistacia lentiscus, Khalaj et al. (2011) on Gerbera jamesonii L., Khattak et al. (2011) on Vinca rosea, Habib (2012) on Caryota mitis Lour, Aklibasinda et al. (2011) on Pinus sylvestris, Abouzar (2012) on Ficus benjamina, Alidoust et al. (2012) on Dracaena and Waseem et al. (2013) on Matthiola incana. 
The abovementioned results of fertilization are in harmony with those attained by Singh et al. (2002) on Gladiolus grandiflorum, Pal and Biswas (2005) on Polianthes tuberosa L., El-Malt et al. (2006) on Hippeastrum vittatum, Youssef and Goma (2007) on Iris tingitana, El-Naggar and El-Nasharty (2009) on Hippeastrum vittatum, Abd El-All (2011) on Aspidistra elatior, Rodrigo et al. (2011) on Pinus nigra and Betula papyrifera, Habib (2012) on Caryota mitis Lour, Wanderley et al. (2012) on areca bamboo palm (Dypsis lutescens) and Youssef and Abd El-Aal (2014) again on Hippeastrum vittatum.

In conclusion, growing Beaucarnea recurvata plants in medium containing composted leaves+ peat moss+ vermiculite or medium containing clay+ sand + peat moss (1:1:1 by volume) and fertilized with kristalon fertilizer at $6 \mathrm{~g} /$ pot is necessary for improving the growth, quality and nutritional status of the plants.

\section{References}

Abd El-All, S.G. (2011): Response of cast-iron plant (Aspidistra elatior Blume) to foliar nutrition with greenzit and $\mathrm{GA}_{3}$. M.Sc. Thesis, Fac. Agric., Benha Univ. 129 pp.

Abou El-Ella, E.M. (2007): Physiological studies on Acanthus mollis plant. M.Sc., Thesis, Hort. Dept. Fac. Agric., Benha Univ.

Abouzar, A., S. Rouhi; A. Eslami and B. Kaviani (2012): Comparison of the effect of different soilless growing media on some growth characteristics of Benjamin Tree (Ficus benjamina). Int. J. Agric. Biol., 14: 985-988.

Aklibasinda, M.; T. Tunc; Y. Bulut and U. Sahin (2011): Effects of different growing media on scotch pine (Pinus sylvestris) production. The Journal of Animal \& Plant Sciences, 21(3), 535541.

Alidoust, M.; M. Torkashvand and M.A. Khomami (2012): The effect of growth medium of peanut shelles compost and nutrient solution on the growth of Dracaena. Annals of Biological Research, 3 (2):789-794.

Bashir, M.A.; M. Ahmad and M.A. Anjum (2007). Effect of various potting media on growth of rooted jojoba (Simmondsia chinensis) cuttings. International Journal of Agriculture and Biology, Vol.9, 147-151.

Berghage, R.D.; R.D. Heins; M. Karlsson; J. Erwin and W. Carlson (1989). Pinching technique influences lateral shoot development in poinsettia. J. Amer. Soc. Hort. Sci. 114(6): 909914.

Brown, J.D. and O. Lilleland (1946): Rapid determination of potassium and sodium in plant material and soil extract by flame photometry. Proc. Amer. Soc., Hort., Sci., 48:341-346.

Chavez, W.; A.D. Benedetto; G. Civeira and R. Lavado (2008): Alternative soilless media for growing Petunia hybrida and Impatiens wallerana: Physical behavior, effect of fertilization and nitrate losses. Bioresource Technology, Vol.99, 8082-8087.

El-Khateeb, M.A.; E.E. El-Maadawy and A.B. ElAttar (2006): Effect of growing media on growth and chemical composition of Ficus alii plants. Annals of Agric. Sc., Moshtohor, Vol. 44(1): 175-193.

El-Malt, A.A.T.; E.E. El-Maadawy; M.A. ElKhateeb and Z.H. El-Sadak (2006): Physiological studies on Hippeastrum vittatum L. plants.2- Effect of NPK, CCC and BA on growth, bulblet production and flowering. Egypt.J. of Appl. Sci., (6B): 724-742.

El-Naggar, A.H. and A.B. El-Nasharty (2009): Effect of growing media and mineral fertilization on growth, flowering, bulbs productivity and chemical constituents of Hippeastrum vittatum, Herb. American-Eurasian J. Agric. \& Environ. Sci., 6 (3): 360-371.

Habib, A. (2012): Effect of NPK and growing media on growth and chemical composition of fishtail palm (Caryota mitis Lour). Life Science Journal ;9(4), 3159- 3168.

Hartmann, H.T.; D.E. Kester; F.T. Davies and R.L. Geneve (2002): Plant Propagation Principles and Practices. Prentice Hall, Upper Saddle River, New Jersey, USA. 702 pp.

Herath H.E.; S.A. Krishnarajah and J.W. Damunupola (2013): Effect of two plant growth hormones and potting media on an ornamental foliage plant, Ophiopogon sp. Int. Res. J. Biological Sci., Vol. 2(12), 11-17.

Herbert, D.; P.J. Phipps and R.E. Strange (1971): Determination of total carbohydrates. Methods in Microbiology, 5 (8): 290-344.

Hussein, M.M.M (2009): Effect of giberellic acid and chemical fertilizers on growth and chemical composition of Cryptostegia grandiflora, $\mathrm{R}$. Br. Plants. T. Hort. Sci. \& Ornamen. Plants, 1(2): $27-$ 38.

Ikram , S.; U. Habib and N. Khalid (2012): Effect of different potting media combinations on growth and vase life of tuberose (polianthes tuberosa linn.). Pak. J. Agri. Sci., Vol. 49(2), 121-125.

Ismail, E.A.S. (2004): Physiological studies on Beaucarnea recurvata. Ph.D. Thesis, Fac. Agric., Zagazig Univ., 180 pp.

Kakoei F. and H. Salehi (2013): Effects of different pot mixtures on spathiphyllum (Spathiphyllum wallisii Regel) growth and development. Journal 
of Central European Agriculture, 14(2), p.140148.

Khalaj, M. A.; M. Amiri and S.S. Sindhu (2011): Study on the effect of different growing media on the growth and yield of gerbera (Gerbera jamesonii L.). Journal of Ornamental and Horticultural Plants, 1(3): 185-189.

Khattak A.; I. Ahmad; N. Amin; F. Wahid and H. Rahman (2011): Effects of different amended organic media on the growth and development of Vinca rosea 'Victory'. Sarhad j. Agric. Vol.27, No.2, 201-205.

Khayyat, M.; F. Nazari and H. Salehi (2007): Effects of different pot mixtures on pothos (Epipremnum aureum Lindl. and Andre 'Golden Pothos') growth and development. Am-Euras. Journal of Agriculture and Environmental. Sciences, Vol.2, 341-348.

Khelikuzzaman, M.H. (2007): Effect of different potting media on growth of a hanging ornamental plant (Tradescantia sp.). J. Trop. Agric. and Fd. Sc. 35(1): 41-48.

Kiran, M.; J. Din; K. Waseem; M.S. Jilani and M.Q. Khan (2007): Effect of different growing media on the growth and development of Dahlia (Dahlia pinnata) under the agro-climatic condition of Dera Ismail Khan, Pakistan Journal of Biological Sciences, Vol.10, 4140-4143.

Koshioka, M.; J. Harda; M. Noma; T. Sassa; K. Ogiama; J.S. Taylor; S.B. Rood; R.L. Legge and R.P. Pharis (1983): Reversed - phase C18 high performance liquid chromatography of acidic and conjugated gibbberellins. J. Chromatgr., 256:101-115.

Lambers, H.; F.S. Chapin and T.L. Pons (2000): Plant Physiology Ecology. Springer - verleg New Yourk.Inc., 540 pp.

Marschner, H. (1997): Mineral Nutrition of Higher Plants. Second Printing, Academic press INC. San Diego, 889 pp.

Mengel, K. and A. Kirkby (1987): Principles of Plant Nutrition. 4th Ed. International, Potash, Institute, Bern, Switzerland, 849 pp.

Muhabat Shah, A. Khattak and N. Amin (2006): Effect of different growing media on the rooting of Ficus binnendijkii 'Amstel Queen' cuttings. Journal of Agricultural and Biological Science. VOL. 1, NO. 3, 15-17.

Nicander, B.; U. Stahl; P. Bjorkman and E. Tillberg (1993): Immyno affinity co-purification of cytokinins and analysis by high-performance liquid chromatography with ultra violet spectrum deterction. Planta, 189: 312-320.

Ostos, J.C.; R. Lopez-Garrido; J.M. Murillo and R. Lopez (2008): Substitution of peat for municipal solid waste and sewage sludge-based composts in nursery growing media: Effects on growth and nutrition of the native shrub Pistacia lentiscus L, Bioresource Technology, Vol.99, 1793-1800.

Pal, A.K. and B. Biswas (2005): Response of fertilizer on growth and yield of tuberose (Polianthes tuberosa L.) cv. Calacutta Single in the plains of West Bengle. J. Interacademicia, Nadia, India, 9(1): 33-36.

Pregl, F. (1945): Quantitative organic micro analysis. 4th ED. J. \& Achurnil, London. Regul., 4: 111-122.

Riaz, A.; M. Arshad; A. Younis; A. Raza and M. Hameed (2008): Effects of different growing media on growth and flowering of Zinnia elegans cv. Blue Point .Pak. J. Bot., 40(4): 1579-1585.

Ribeiro, H.M.; A.M .Romero; H. Pereira; P. Borges; F. Cabral and E. Vaconcelos (2007): Evaluation of a compost obtained from forestry wastes and solid phase of pig slurry as a substrate for seedlings production. Bioresource Technology, Vol.98, 3294-3297.

Rodrigo A.C.; P. Bonello and D.A. Herms (2011): Effect of the growth regulator paclobutrazol and fertilization on defensive chemistry and herbivore resistance of austrian pine (Pinus nigra) and paper birch (Betula papyrifera.). Arboriculture \& Urban Forestry 2011. 37(6): 278-287.

Salisbury, F.B. and C.W. Ross (1974): Plant Physiology. Publishing Inc. Belmont. California, 2nd ed., pp. 422.

Singh,W.; S.K. Sehrawat; D.S. Dahiya and K. Singh (2002): Leaf nutrient status of gladiolus (Gladiolus grandiflorus L.) cv. Sylvia as affected by NPK application. Haryana Journal of Horticultural Sciences, Horticultural Society of Haryana, Hisar, India, 31(1/2): 49-51.

Snedecor, G.W. and W.G. Cochran (1989): Statistical methods. 7th Ed. Iowa State Univ. Press. Ames Iowa, USA, 503 pp.

Suresh, K.D.; G. Sneh; K.K. Krishn and C.M. Mool (2004). Microbial biomass carbon and microbial activities of soils receiving chemical fertilizers and organic amendments. Arch. Agron. Soil Sci., 50: 641-647.

Tahir, M.; W. Ahmad; K.S. Ahmad; J. Shafi; M.A. Shehzad and M.A. Sarwar (2013): Comparative effect of different potting media on vegetative and reproductive growth of Floral Shower (Antirrhinum majus L.). Universal Journal of Plant Science 1(3): 104-111.

Trouge, E. and A.H. Meyer (1939): Improvement in deiness calorimetric for phosphorus and arsenic. Ind. Eng. Chem. Anal. Ed., 1; 136-139.

Turhan, H.; F. Kahriman; C.O. Egesel and M.K. Gul (2007): The effects of different growing media on flowering and corm formation of 
saffron (Crocus sativus L.). African Journal of Biotechecnology, Vol.6, 2328-2332.

Wanderley, C.S.; R.T. Faria and M.U. Ventura (2012): Chemical fertilization, organic fertilization and pyroligneous extract in the development of seedlings of areca bamboo palm (Dypsis lutescens). Maringá, V. 34, N. 2, p. 163167.

Waseem, K.; A. Hameed; M.S. Jilani; M. Kiran; M. Rasheed; S. Javeria and T.A. Jilani (2013): Effect of different growing media on the growth and flowering of stock (Matthiola incana) under the agro-climatic condition of Dera Ismail Khan. Pak. J. Agri. Sci., Vol. 50(3), 523-527.

Younis, A.; A. Riaz; M. Waseem; M.A. Khan and M. Nadeem (2010): Production of quality croton (Codiaeum variegatum) plants by using different growing media. Journal of Agriculture and Environmental Science., Vol.7, 232-237.
Yousif, A.A. and S.M. Kako (2012): Effect of growing media on growth and flowering of different hyacinth cultivars (Hyacinthus orientalis L.). Journal of Agricultural Science and Technology., B 2, 1100-1108.

Youssef, A.S.M. and M.M.M Abd El-Aal (2014): Effect of kinetin and mineral fertilization on growth, flowering, bulbs productivity, chemical composition and histological features of Hippeastrum vittatum plant. J. plant production, Mansoura Univ., Vol (3):357-681

Youssef, A.S.M. and A.O. Gomaa (2007): Effect of some horticultural treatments on growth, flowering, bulb production and chemical composition of Iris tingitana cv. Wedgwood. The Third Conf. of Sustain. Agric. and Develop. Fac. of Agric., Fayoum Univ., 12-14 Nov., p:299326. 


\section{الملغص العربي}

تأثثير بيئات النمو المختلفه والتسميد الكيماوي علي النمو والمحتوي الكيماوي لنبات البوكارنيا

\section{أحمد سعيد محمد يوسف - الحفة \\ قسم البساتين - كلية الزراعة - جامعة بنها - مصر بـاعل}

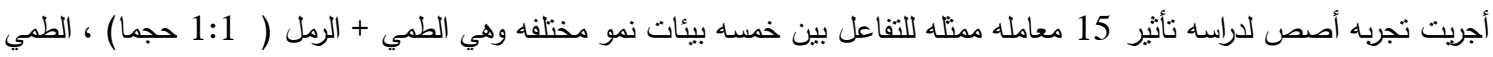

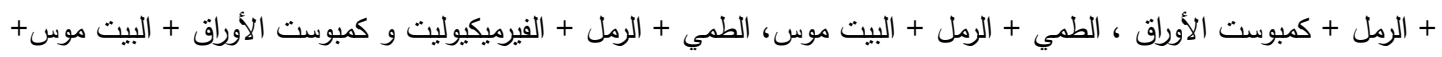

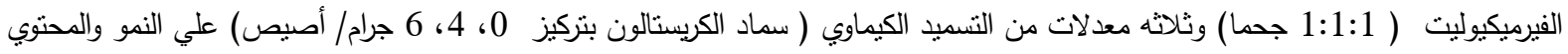

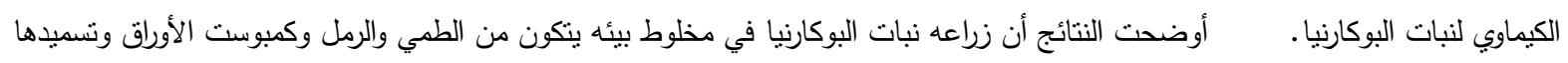

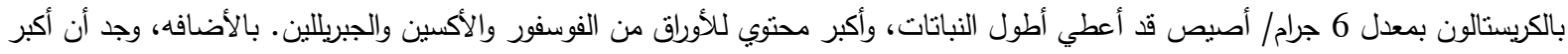

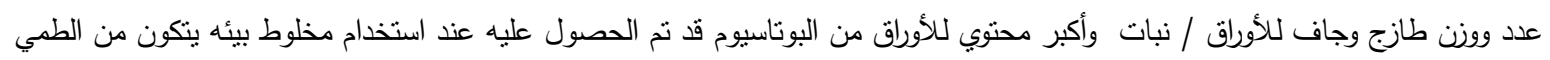

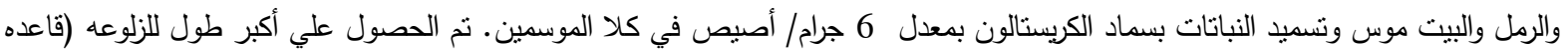

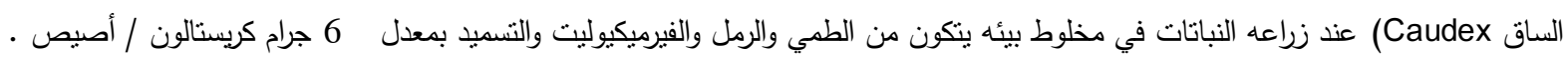

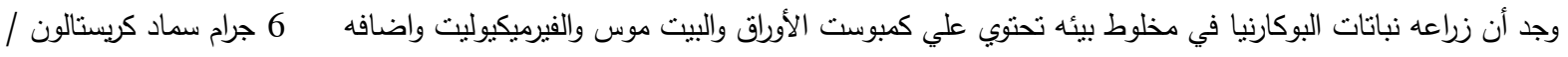

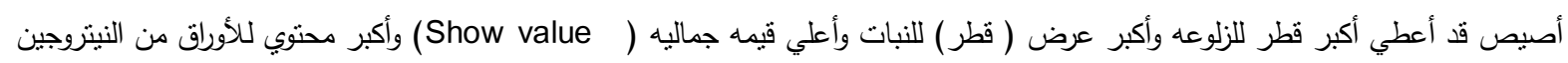
والكربوهيدرات والسيتوكينين بالأضافه الي أقل محتوي للأوراق من حمض الأبسر البسيسيك.

وبناءا علي النتائج المتحصل عليها وجد أن زراعه نباتات البوكارنيا في بيئه تحتوي علي كمبوست الأوراق والبيت موس والفيرميكيوليت أو

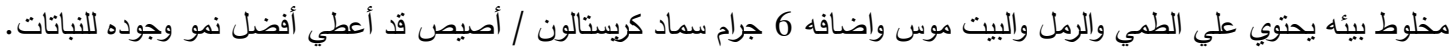

